Portland State University

PDXScholar

$11-17-2017$

\title{
Microplastic Concentrations in Crassotrea gigas: Establishing a Baseline of Microplastic Contamination in Oregon's Oyster Aquacultures
}

Mia K. Jauregui

Portland State University

Follow this and additional works at: https://pdxscholar.library.pdx.edu/honorstheses Let us know how access to this document benefits you.

\section{Recommended Citation}

Jauregui, Mia K., "Microplastic Concentrations in Crassotrea gigas: Establishing a Baseline of Microplastic Contamination in Oregon's Oyster Aquacultures" (2017). University Honors Theses. Paper 494.

https://doi.org/10.15760/honors.497

This Thesis is brought to you for free and open access. It has been accepted for inclusion in University Honors Theses by an authorized administrator of PDXScholar. Please contact us if we can make this document more accessible: pdxscholar@pdx.edu. 
Microplastic concentrations in Crassotrea gigas: establishing a baseline of microplastic contamination in Oregon's oyster aquacultures

by

Mia Jauregui

An undergraduate honors thesis submitted in partial fulfillment of the

Requirements for the degree of

Bachelor of Science

in

University Honors

and

Environmental Science

Thesis Advisor

Elise Granek

Portland State University

2017 


\section{Acknowledgments}

I would like to acknowledge my family and friends who gave me guidance and support during my time as an undergraduate. Mom, Dad, and Erika, thank you for supporting me regardless of my pursuits, it means the world to me.

I would also like to thank Britta Baechler and Dr. Granek, who allowed me to be a part of this important research. I learned and gained so much valuable experience and I will forever be grateful. 


\begin{abstract}
Anthropogenic debris is "found across all habitats in the ocean, including coral reefs, shallow bays, estuaries, the open ocean, and the deep sea" (Rochman et al., 2015). Microplastic pollution is widespread in the marine environment and poses a threat to a variety of organisms, including commercial shellfish grown for human consumption. The aim of this study is to establish a baseline of microplastic evidence in Oregon through the examination of Crassotrea gigas--or the Pacific Oyster. In addition it hopes to determine if there are differences in microplastic concentration geographically and temporally. Five oyster samples were collected in Spring 2017 from a total of six sites, three Northern and three Southern to establish a geographic range of XXXX Pacific oyster aquacultures. Another five oyster samples were collected from a single Northern site during Summer 2017 to address temporal variation. Microplastics were extracted using a $10 \% \mathrm{KOH}$ solution and identified under a dissecting microscope. The research suggests that there is no significance difference geographically or temporally. However, the study does establish the uptake of microfibers by Pacific oysters, which could not only harm the organism, but raises concern for human consumption.
\end{abstract}

\title{
Introduction
}

Worldwide the marine environment is heavily polluted with plastic debris and over 260 species have been documented to ingest or become entangled in plastics (Teuten et al. 2007). The demand for plastic products increased from approximately 1.5 million tonnes in the 1950 s to 280 million tonnes in 2011, suggesting a continuous influx into the world's oceans (Wright et al. 2013) (Figure 1). Specifically, plastics make up about 60 to $80 \%$ of all marine debris (Setala, 2014). Plastics easily accumulate, not only due to their high levels of production, but also due to their physical characteristics, like slow biodegradation and chemical inertness (Espinosa et al. 
2016). Of the plastic debris, microplastics, are defined by the National Oceanic and Atmospheric Administration (NOAA) as being less than $5 \mathrm{~mm}$. Microplastics occur in size ranges similar to many organisms from the benthos and plankton communities and can also be comparable in size to sediments, highlighting the potential ingestion by various organisms. (Hidlago-Ruz, 2012). Microplastics are introduced through primary sources, meaning they are purposefully manufactured to be microscopic; or secondary sources, where they are fragments of larger pieces of plastic (Wright et al. 2013). Currently, no method exists to determine the lifetime of microplastics in the marine environment, reiterating the importance of research to develop a better understanding (Hidalgo-Ruz, 2012). The aim of this study is to establish a baseline of microplastic research in Oregon. Specifically, Crassotrea gigas, or the Pacific Oyster, will be examined to determine if there are microplastics present in their tissues and if the concentrations differ between the coastal North and South. The study will also compare a single site from Spring and Summer to determine seasonal variation. 


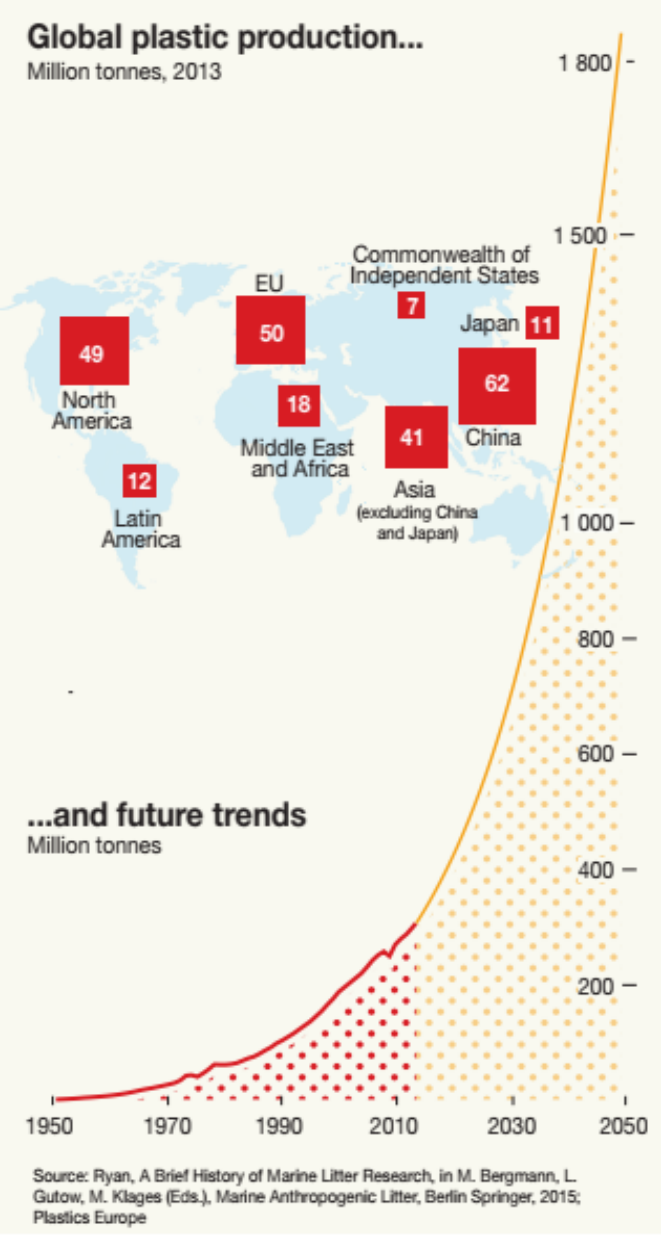

Figure 1: Displays the current and estimated trendline of future plastic production in million tonnes (Baker et al. 2016).

\section{Microplastic Pathways of Introduction}

\section{Secondary Sources}

The most common manufactured polymers are composed of polyethylene, polypropylene and polystyrene (Hidalgo-Ruz, 2012). Plastic polymers have an unknown, but long lifetime allowing them to persist in the marine environment for decades (Moos, 2012). Microplastics can be introduced through secondary sources, which is the degradation of larger plastics. Degradation is caused by biological breakdown, photodegradation, chemical weathering and 
physical forces (Hidlago-Ruz, 2012). The shape of a microplastic depends on the fragmentation process and the residence time in the environment (Hidlago-Ruz, 2012). Sharp edges suggest recent introduction or the breakup of larger pieces, where pieces with smooth edges are typically older and have been weathered (Hidalgo-Ruz, 2012).

Primary Sources

Microplastics are also directly introduced into the environment through human manufacture and activity (Moos et al, 2012). One mode of introduction is through the transport and handling processes of materials that are used to make plastics, where the granules and resin pellets are released into the ocean (Moos et al. 2012). Also, ship-breaking yards directly introduce microplastics from the use of scrubbers and abrasive beads used to clean ships (Teuten et al. 2007). In one Indian ship-breaking yard there were microplastic concentrations in the water of up to $81 \mathrm{ppm}$ (Teuten et al. 2007). Additionally, sandblasting, which is commonly used in the maritime industry, uses industrial abrasives, which contain microplastics (Moos et al. 2012).

Microbeads are another primary source of microplastic pollution and are often found in cosmetic products that contain exfoliants (Tonge, 2016). Unfortunately, most wastewater treatment plants do not have the proper technology to filter microbeads (Tonge, 2016). Because of the risk that microbeads pose, federal legislation passed the Microbead-Free Waters Act of 2015 that prohibits the manufacture and sale of microbead products throughout the United States and will enter the final stages by 2019 (Tonge 2016).

Interestingly, fibrous microplastics--originating from synthetic textiles--are recognized as the most abundant form of microplastics in the marine environment (Wright et al. 2013). A variety of fibers are used in the the production of textiles, such as natural, synthetic, and natural/synthetic blends (Napper et al. 2016). Synthetic fibers have been used as a supplement 
for natural fibers for over fifty years and washing of such fabrics poses a potential source of introduction of microplastic fibers to aquatic habitats (Napper et al. 2016). Waste effluent from washing machines travels to wastewater treatment plants and often a large portion of fibers pass through the preliminary treatment screens (fine screens 1.5-6 mm) (Napper et al. 2016).

One study sampled a domestic washing machine's wastewater and found that one garment could produce > 1900 fibers per wash (Browne et al. 2011). Interestingly, a study that compared anthropogenic debris in bivalve tissue in Indonesia and the U.S. discovered that debris in the U.S. was mostly composed of fibers (Rochman et al. 2015). Numerous other studies show the prevalence of microfibers in marine biota. For example, a study on the Norway lobster found that $83 \%$ of the studied animals contained microfibers (Setala, 2014). Another study on microplastic ingestion in bivalves in China found 4.3 to 57.2 microplastics per individual and microfibers accounted for more than half of the items found (Li et al. 2015). Overall, it can be expected that most microplastics found will be microfibers, since previous research revealed that most microplastics found in subtidal and estuarine sediments are fibers (Hidalgo-Ruz, 2012).

\section{Ocean Contamination}

Microplastics are dispersed by winds and currents and are present even in the most remote areas (Moos, 2012). Over time "plastics at the water surface accumulate in gyres, or sink to the sea bed due to waterlogging in sediments, or are washed ashore and litter coastlines" (Moos, 2012). The North Pacific gyre--nearest to the Oregon coast--is heavily polluted with plastics and has a high rate of $10 \mathrm{~kg}$ per square $\mathrm{km}$ in the center (Baker et al. 2016) (Figure 2). Typically the water approaching the center of the gyre has to exit and does so by sinking, but plastics are often too buoyant and remain trapped in the converging current causing excessive buildup (Baker et al. 2016). 


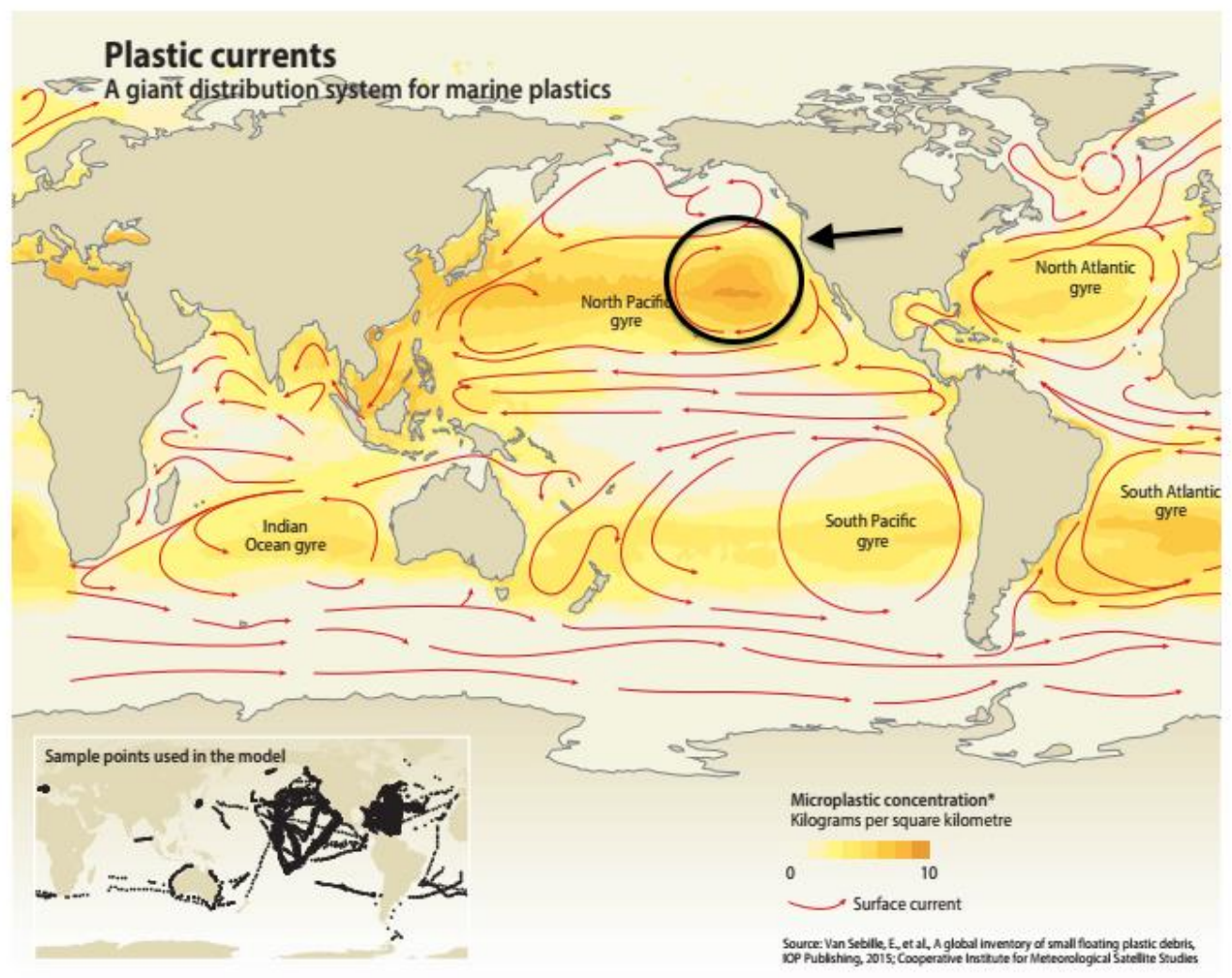

Figure 2: Graphical representation of the world's gyres with their relative microplastic concentration $\left(\mathrm{kg} / \mathrm{km}^{\wedge} 2\right)($ Baker et al. 2016). The black arrow indicates the Oregon coast and circle depicts the portion of the North Pacific gyre that is nearest with its relative microplastic concentration.

\section{Contaminants and Trophic Level Transfer}

During manufacture, additives are added to plastics to enhance their performance, which often are active in absorbing other contaminants, making plastics a vector (Espinosa et al. 2016). Teuten et al. (2007) addresses that plastic debris can have high concentrations of hydrophobic organic contaminants, which include compounds like pesticides, petroleum hydrocarbons and solvents. "Many plastics are less dense than water and float at the sea-surface microlayer (SML) where hydrophobic compounds can be concentrated up to 500 times that of the underlying water column", providing a mode of transport for contaminants (Teuten et al. 2007). In their study, the 
organism A. marina--a benthic deposit feeder--was shown to ingest microplastics, suggesting the potential ingestion of sorbed hydrophobic contaminants (Teuten et al. 2007). The study describes the potential for trophic level transfer, as A. marina is low on the food chain and eaten by other organisms.

\section{Pacific Oyster}

For the purpose of this study the test organism chosen was the bivalve Crassostrea gigas, or the Pacific oyster. The Pacific oyster was introduced to the United States in 1903 from Japan and has become a large commercial fishery (Pauley et al. 1988). A Pacific oyster ranges in length from $101.6 \mathrm{~mm}$ to $152.4 \mathrm{~mm}$ (Pauley et al. 1988). They are protandrous hermaphrodites, meaning their male reproductive organs come to maturity before their female organs (Pauley et al.1988). They function as separate male or female organisms during a spawning cycle, but a change of sex often occurs at some point during their lives (Pauley et al. 1988). Pacific oysters spawn annually and synchronously, which is typically activated by water temperature (Pauley et al. 1988). An average sized female oyster is highly prolific and produces between 50-100 million eggs in a single spawning (Pauley et al. 1988). In favorable conditions fertilized eggs will develop into the shelled veliger stage where they are planktotrophic larvae--feeding on phytoplankton (Pauley et al.,1988). Larval growth depends primarily on water temperature, which is optimal at $20^{\circ} \mathrm{C}$ or higher (Pauley et al. 1988). Larval dispersal and settlement is determined by ocean currents and is usually broad if there is suitable habitat (Pauley et al. 1988). Larvae attach to substrate with their foot once they reach the length of about $0.30 \mathrm{~mm}$ (Pauley et al. 1988).

Pacific oysters are filter feeders that feed on planktonic organisms that are filtered by the gills, entrapped and bound in mucus (Pauley et al. 1988). The mucus is then carried to the labial 
polyps, where they are sorted to the mouth or rejected as pseudofeces (Pauley et al. 1988). Food is then carried by the mucus strings to the alimentary canal and sorted again by the caecum (Pauley et al. 1988). Oysters can filter particles smaller than $2 \mu \mathrm{m}$ and their stomach contents have been shown to not fully represent planktonic consumption, rather contents consist of a variety: bacteria, protozoa, phytoplankton, larval forms of invertebrate animals, detritus and some inorganic material.

\section{Methods}

\section{Sample Collection}

For the purpose of this study, five Pacific oysters were purchased from six Oregon shellfish vendors during Spring 2017: three in the Northern coastal range and three in the Southern. The vendors will remain anonymous to assure their privacy. The organisms were handled using gloves and were placed into 64 ounce mason jars with gridded lids for air flow to ensure no cross contamination. The jars were then labeled by species, site and date and placed into an ice chest. Ice chests were used to transfer the samples back to Portland State University (PSU). Ice was distributed into the bottom of the chest and then covered with $100 \%$ cotton cloths, again to avoid cross contamination. Five more oysters were purchased during late Summer 2017 from a single northern site. The same collection and transportation methods were followed for the final sample.

\section{Shucking}

The organisms were processed through the method of shucking. Individually each oyster was weighed and measured in length, width and height. The oyster was then removed from its shell using a scalpel. Mass of the tissue weight and shell weight were taken separately and recorded. The shell was disposed, while the tissue was placed into an 8 ounce mason jar, which 
was previously rinsed twice with deionized water to eliminate contamination. All tissue was rinsed off of the tray using deionized (DI) water. The jar was then labeled corresponding to the individual number, site, organism and date. Jars were then placed into the freezer to be preserved for tissue digestion.

\section{Tissue Digestion}

The samples were removed from the ice chest to thaw and five $600 \mathrm{~mL}$ beakers were labeled to the corresponding samples. The beakers were then rinsed three times with DI water along with eight watch glasses. Once thawed the liquid was poured into the corresponding beaker and the tissue weight was recorded. The tissue was then placed into the beaker and the tray was rinsed using DI water to assure all of the contents were transferred to the beaker. A stir bar was then added to each beaker. Next, a $10 \%$ potassium hydroxide solution was used to break down the tissue. Specifically, $270 \mathrm{~mL}$ of DI water was added to each beaker, after which $30 \mathrm{~g}$ of potassium hydroxide $(\mathrm{KOH})$ was added. The hot plate was turned on to $60^{\circ} \mathrm{C}$ and the stir function was set to $500 \mathrm{rpm}$. The samples were left to digest for a total of 24 hours (Rochman et al. 2015).

\section{Filtration and Drying}

After 24 hours the samples were removed from the hot plates. Five petri dishes were labeled corresponding to the beakers. Five clean beakers and watch glasses were rinsed three times and placed under the fume hood. A stainless steel, 63 micron sieve was rinsed three times with DI water, inverted and covered with a watch glass to ensure no cross contamination. The sieve was held over the clean beaker and the sample was poured through. The beaker was then rinsed thoroughly with DI water to assure all of the digested material went into the sieve. Afterwards the sieve was held over the corresponding petri dish and a DI squirt bottle was used 
to rinse the contents into the petri dishes. The samples were then covered to ensure no cross contamination and moved into the drying oven where they were dried for 24 hours at $40^{\circ} \mathrm{C}$. The excess liquid from the samples were poured into a chemical waste bottle labeled ' $10 \% \mathrm{KOH}$ waste'.

\section{Microplastic Identification \& Quantification}

Once the samples were dried, they were then examined using a dissecting microscope. The petri dishes had sections 1-16 to ensure microplastics were not double counted. Beginning at section one the top layer of the sample was first observed. If any plastics were found, a picture was taken using the Leica microscopes software (Figure 3). From the picture, the plastic was then measured in millimeters (Figure 4). When a plastic was found the type of plastic was determined--microfiber or microfragment--followed by assessing and recording the color of the plastic. The same steps were used to address the bottom layer of the sample. A procedural blank-a petri dish with DI water only--was left uncovered during identification to account for any cross contamination.

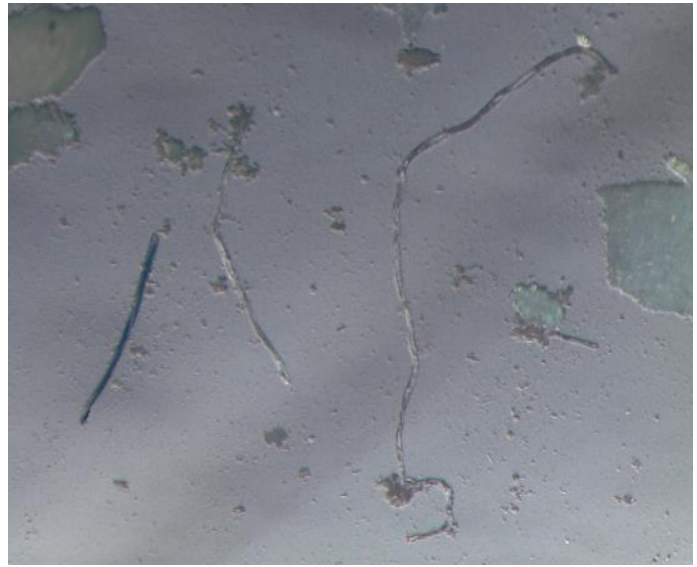

Figure 3: Image of one blue and two clear fibers within a sample.

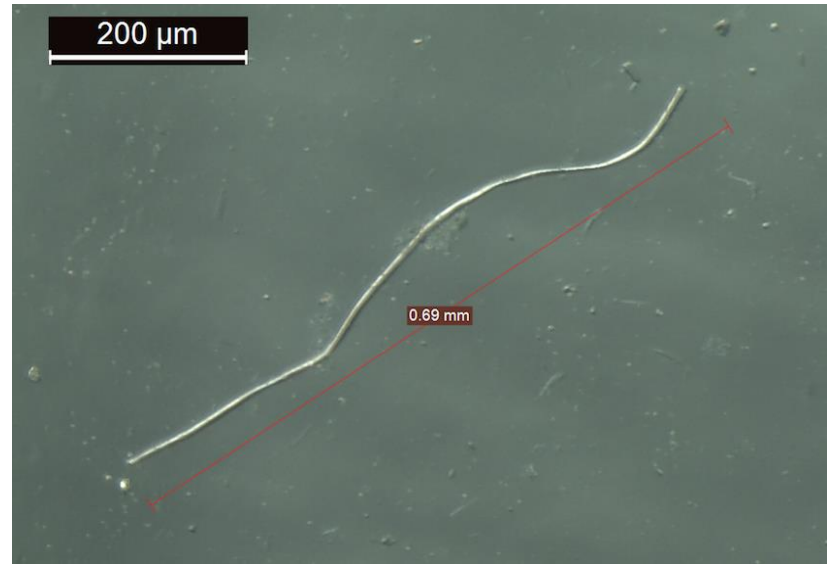

Figure 4: Image of a single clear fiber and its associated measurement. 


\section{Results}

\section{Northern Sites}

To ensure vendor anonymity Northern coastal sites were denoted as A, B, and C. An average of oyster sizes were taken across Northern sites in order to provide that they are comparable in size to Southern sites (Table 1). Site A was found to have an average of $16.6+/-$ 5.446 microfibers per individual. A total of 83 fibers were found in the five samples and $56.6 \%$ were determined to be clear fibers. Site B had an average of $15.2+/-2.990$ microfibers per individual. A total of 76 fibers were found and $84.2 \%$ were clear fibers. Site $\mathrm{C}$ had an average of $12+/-4.785$ per individual. A total of 60 fibers were found in the five samples with $66.67 \%$ clear fibers. Color variation of all Northern sites is as follows: $68.950 \%$ clear; $20.548 \%$ blue; $7.306 \%$ black; $1.370 \%$ purple; $0.457 \%$ green, pink, red and brown (Figure 5). The average length of a fiber for Northern sites was $1.182+/-0.097 \mathrm{~mm}$. The average number of contaminants found in the procedural blanks were 2.333 microfibers. 
Table 1: The average length, width, height, full weight, shell weight, and tissue weight of the samples from the Northern sites along with their standard deviation.

\begin{tabular}{|l|l|l|l|l|l|l|}
\hline & $\begin{array}{l}\text { Shell length } \\
(\mathrm{mm})\end{array}$ & $\begin{array}{l}\text { Shell Width } \\
(\mathrm{mm})\end{array}$ & $\begin{array}{l}\text { Shell } \\
\text { Height } \\
(\mathrm{mm})\end{array}$ & $\begin{array}{l}\text { Full Weight } \\
(\text { shell }+ \\
\text { body) }(\mathrm{g})\end{array}$ & $\begin{array}{l}\text { Shell } \\
\text { Weight (g) }\end{array}$ & $\begin{array}{l}\text { Tissue } \\
\text { Weight (g) }\end{array}$ \\
\hline $\begin{array}{l}\text { Northern } \\
\text { Sites } \\
\text { Average }\end{array}$ & 131.714 & 64.046 & 32.818 & 144.036 & 105.936 & 25.076 \\
\hline $\begin{array}{l}\text { Northern } \\
\text { Sites } \\
\text { Standard } \\
\text { Deviation }\end{array}$ & 13.209 & 7.512 & 6.167 & 21.477 & 16.752 & 4.274 \\
\hline $\begin{array}{l}\text { Southern } \\
\text { Sites } \\
\text { Average }\end{array}$ & 108.627 & 62.456 & 32.874 & 142.140 & 97.675 & 31.078 \\
\hline $\begin{array}{l}\text { Southern } \\
\text { Sites } \\
\text { Standard } \\
\text { Deviation }\end{array}$ & 25.509 & 15.949 & 7.651 & 41.600 & 28.232 & 10.369 \\
\hline
\end{tabular}

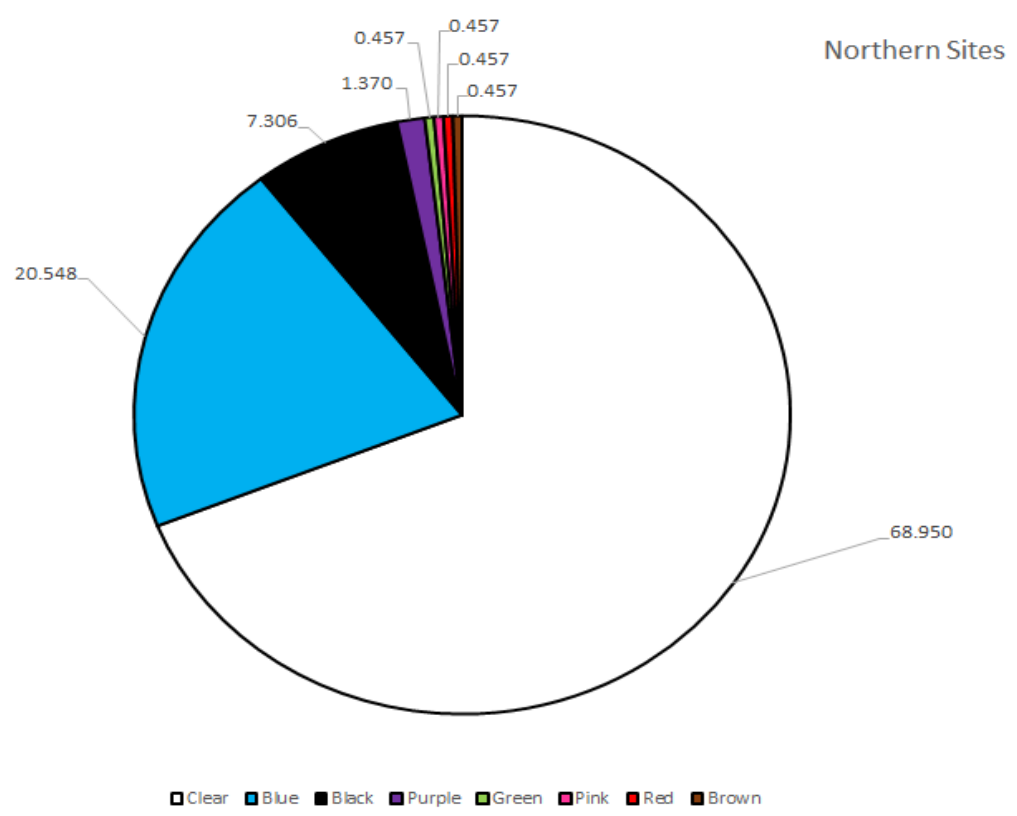

Figure 5: Displays the color percentages of microfibers found within Northern sites. 


\section{Southern Sites}

Southern sites will be denoted as D, E, and F, again to maintain anonymity of shellfish vendors. An average of oyster size was taken across Southern sites to establish they are comparable to Northern sites (Table 1). Site D had an average of $17+/-3.899$ microfibers per individual. There was a total of 85 fibers found across 5 individuals and the majority of fibers were clear $(84.706 \%)$. Site E had an average of $22.8+/-7.060$ microfibers per individual. A total of 114 fibers were found and approximately $73.684 \%$ were clear colored. Site F had an average of $15.2+/-2.800$ fibers per individual. A total of 76 fibers were found with $71.053 \%$ clear colored. The color demographic of all southern sites is as follows: $76.364 \%$ clear; $15.636 \%$ blue; 4.727 black; 1.818 brown; 0.727 red; 0.364 pink and green (Figure 6). The average length of a for Southern sites was $1.152+/-0.085 \mathrm{~mm}$. The average number of contaminants found in the procedural blanks were 3.333 microfibers.

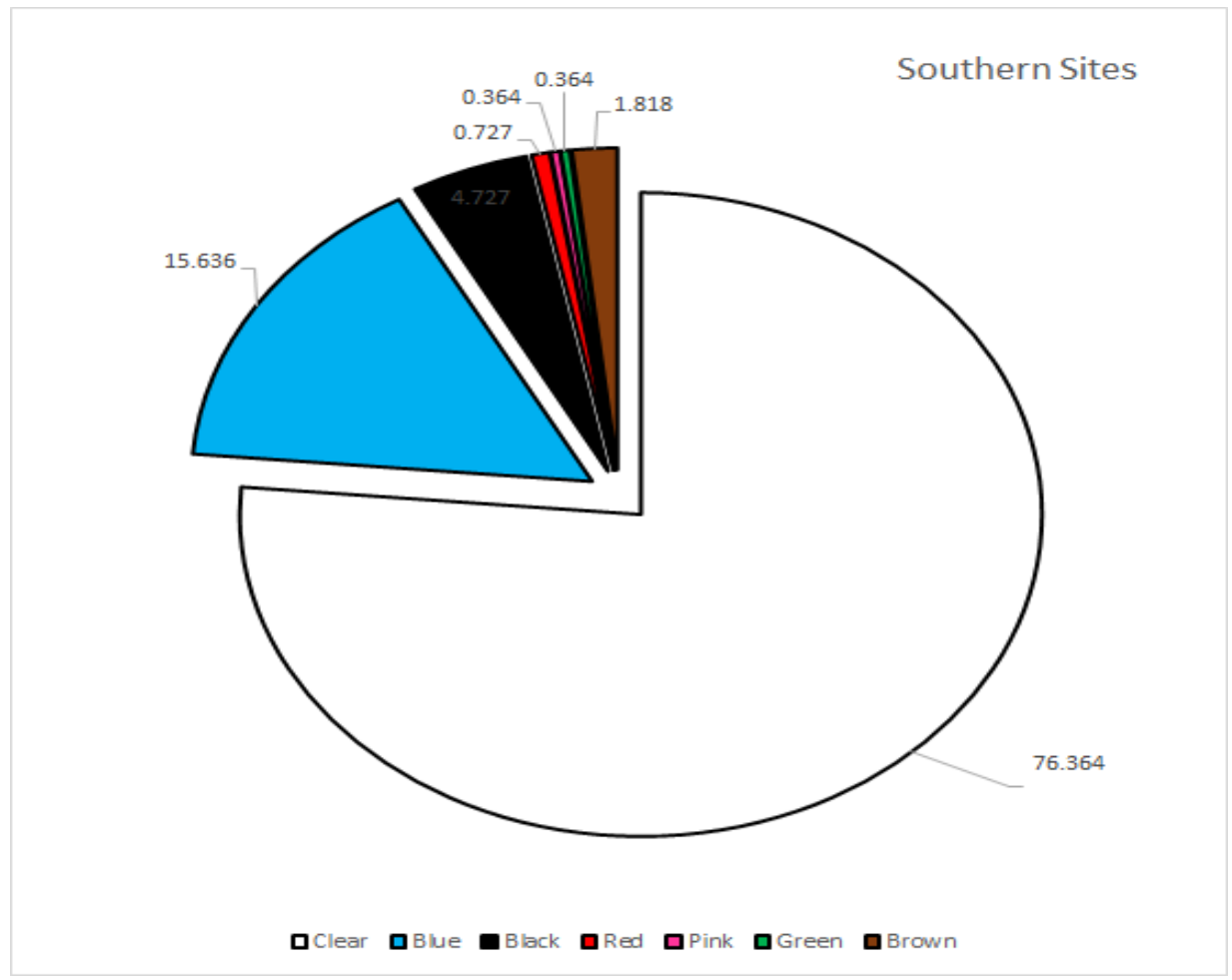

Figure 6: Displays the color percentages of microfibers found within Southern Sites. 


\section{Northern versus Southern}

Northern sites were found to have an average of 14.6 microfibers per individual with a standard deviation of 9.583 , while Southern sites had an average of 18.333 microfibers per individual with a standard deviation of 10.742 (Figure 7). In order to establish that Northern and Southern sites were comparable in size an independent two tailed t-test found a p-value of 0.865 determining there is no significant difference between sizes of oysters of the two groups. An independent two-tailed t-test found a p-value of 0.324 accepting the null hypothesis and determining no significant difference between locations. The average microfiber length across all sites was $1.167 \mathrm{~mm}$. Table 3 represents the average number of microfibers and the average length across all sites.

Table 3: Displays the average number of microfibers from each site, with their associated standard error. It also provides the average microfiber length $(\mathrm{mm})$ across all sites, along with their standard error.

\begin{tabular}{|l|l|l|l|l|l|l|}
\hline Site & $\boldsymbol{A}$ & $\boldsymbol{B}$ & $\boldsymbol{C}$ & $\boldsymbol{D}$ & $\boldsymbol{E}$ & $\boldsymbol{F}$ \\
\hline $\begin{array}{l}\text { Average \# } \\
\text { of } \\
\text { Microfibers }\end{array}$ & 16.6 & 15.2 & 12 & 17 & 22.8 & 15.2 \\
\hline $\begin{array}{l}\text { Standard } \\
\text { Error }\end{array}$ & 5.446 & 2.990 & 4.785 & 3.899 & 7.060 & 2.800 \\
\hline $\begin{array}{l}\text { Average } \\
\text { MFB } \\
\text { Length } \\
\text { (mm) }\end{array}$ & 1.056 & 1.239 & 1.250 & 1.139 & 0.992 & 1.325 \\
\hline $\begin{array}{l}\text { Standard } \\
\text { Error }\end{array}$ & 0.076 & 0.088 & 0.128 & 0.096 & 0.048 & 0.111 \\
\hline
\end{tabular}


Average Number of Microfibers per Site
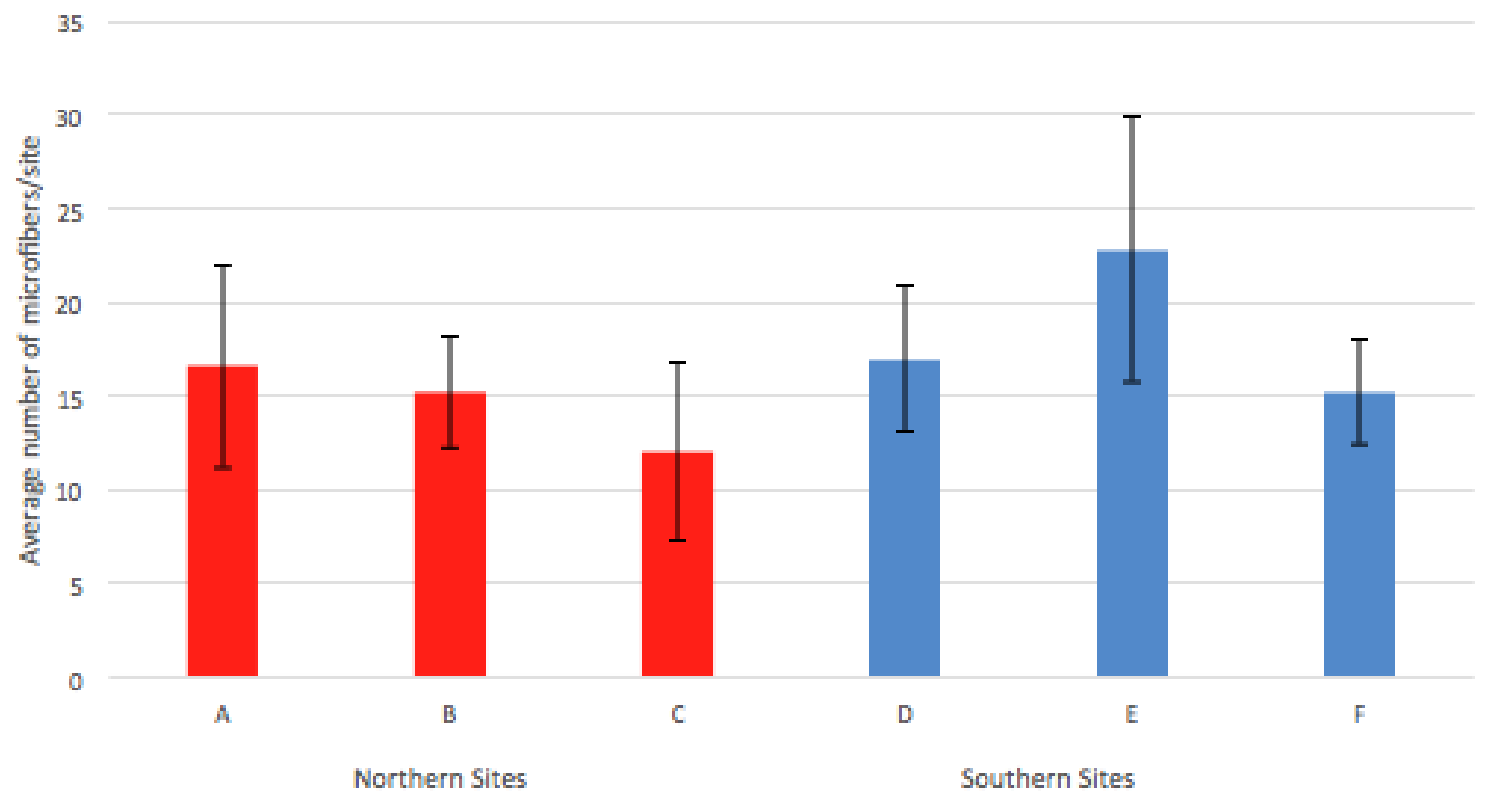

Figure 7: The bar chart portrays the average number of microfibers found from each site along with their associated standard error. It also shows the difference between Northern and Southern sites.

\section{Spring versus Summer}

Site $\mathrm{C}$ was the only site compared across seasons. In Spring the samples had an average of 12 fibers with a standard error 4.785. A total of 60 fibers were found in the five samples, with $66.67 \%$ were clear fibers. Summer samples had an average of 18.6 fibers per individual with a standard error of 3.265. A total of 93 fibers were found in the five samples with $69.893 \%$ clear fibers. A paired two-tailed t-test found a p-value of 0.355 accepting the null hypothesis and determining no significant difference between seasons. 


\section{Discussion}

The present study provides the first record of microplastic polymers in the tissues of Crassotrea gigas grown in Oregon aquacultures for human consumption. $100 \%$ of the oysters contained microfibers, with an average of 16.467 microfibers per individual.

Northern and Southern aquacultures were compared to determine if there was a significant difference between locations and with a p-value of 0.324 we were unable to identify a significance. This study had a small population size of only 30 individuals, and therefore its results may not account for the true differences present between the estuaries of Northern and Southern Oregon. A future study should expand its population size to determine the true significance between locations.

Site $\mathrm{C}$ was compared across spring and summer and with a p-value of 0.355 there was no significant temporal difference. Originally, it was thought that spring samples would contain more microplastics due to weather patterns, specifically rain that causes runoff. This finding suggests that runoff is not a major source of microplastic pollution and again pollution may be determined solely by wastewater.

Both Northern and Southern sites had high standard errors, in regards to the number of microfibers within their tissues, implicating large variations between samples within a site. This finding reiterates the importance of expanding population size.

Previous studies linked wastewater treatment to microplastic ingestion in the U.S. (Rochman et al. 2015). Since all microplastics found were fibers, it is thought that wastewater is the primary mode of introduction to oysters. Future research should compare estuaries that are in 
close proximity to wastewater treatment plants to determine the true source of microfiber pollution.

Plastic pollution in the marine environment is a global problem. It has become a concern that the ingestion of plastic by marine biota may cascade up the food chain to influence human health. The results of this study are alarming since $100 \%$ of the oysters bought from shellfish vendors contained microfibers, which suggests that humans are consuming plastics. Not only that, but plastics have the ability to adsorb a variety of contaminants, thus making them a greater threat to the health of marine biota and humans. In all, this research adds to the growing literature around plastic pollution in the marine environment. 


\section{References}

Browne, M. A.; Crump, P.; Niver, S. J.; Teuten, E.; Tonkin, A.; Galloway, Thompson, R. Accumulation of microplastic of shoreline worldwide: sources and sinks. Environmental Science \& Technology 2011, 45 (21). 9175 - 9179.

Browne, M. A.; Dissanayake, A.; Galloway, T. S.; Lowe, D. M.; Thompson, R. C. Ingested microplastic translocates to the circulatory system of the mussel, Mytilus edulis (L.). Environmental Science \& Technology 2008, 42 (13). 5026 - 5031.

Cauwenberghe, L. V. Janssen, C. R. Microplastics in bivalves cultured for human consumption. Environmental Pollution 2014, 193. 65 - 70.

Espinosa, C. M.; Esteban, A.; Cuesta, A. 2016. Chapter 6: Microplastics in aquatic environments and their toxicological implication for fish. Toxicology - New Aspects to This Scientific Conundrum, InTech Publisher, Eds. Sonia Soloneski and Marcelo L. Larramendy, 113 129.

Farrel, P. Nelson, K. Trophic level transfer of microplastic: Mytilus edulis (L.) to Carcinus maenas (L.). Environmental Pollution 2013, 177. 1-3.

Hidalgo-Ruz, V.; Gutow, L.; Thompson, R. C.; Thiel, M. Microplastics in the marine environment: a review of the methods used for identification and quantification. Environmental Science \& Technology 2012, 46, 3060 - 3075.

Koelmans, A. A.; Besseling, E.; Foekema, E. M. Leaching of plastic additives of marine organisms. Environmental Pollution 2014, 187. 49 - 54.

Lusher, A. L.; McHugh, M.; Thompson, R. C. Occurrence of microplastics in gastrointestinal tract of pelagic and demersal fish from the English Channel. Marine Pollution Bulletin 2012, xxx. Xxx - Xxx.

Moos, N. V.; Burkhardt-Holm, P.; Kohler, A. Uptake and effects of microplastics on cells and tissues of blue mussel Mytilus edulis L. after an experimental exposure. Environmental Science \& Technology 2012, 46. 11327 - 11335.

Rochman, C. M.; Tabir., A; Williams, S. L.; Baxa, D. V; Lam, R.; Miller, J. T.; Teh, F.; Werorilangi, S., Teh, S. J. Anthropogenic debris in seafood: Plastic debris and fibers from textiles in fish and bivalves sold for human consumption. Scientific Reports 2015, 5. $1-10$.

Setala, O.; Lehtinen-Fleming, V.; Lehtiniemi, M. Ingestion and transfer of microplastics in the planktonic food web. Environmental Pollution 2014, 185. $77-83$. 
Teuten, E. L.; Rowland, S. J.; Galloway, T. S.; Thompson, R. C. Potential for plastics to transport hydrophobic contaminants. Environmental Science \& Technology 2007, 41. $7759-7764$.

Teuten, E.; Saquing, J. M.; Knappe, D. R. U.; Barlaz, M. A.; Jonsson, S.; Bjorn, A.; Rowland, S. J.; Thompson, R. C.; Galloway, T. S.; Yamashita, R.; Ochi, D.; Watanuki, Y.; Moore, C.; Viet, P. H.; Tana, T. S.; Prudente, M.; Boonyatumanond, R.; Zakaria, M. P.; Akkhavong, K.; Ogata, Y.; Harai, H.; Iwasa, S.; Mizukawa, K.; Hagino, Y.; Imamura, A.; Saha, M.; Takada, H. Transport and release of chemicals from plastics to the environment and to wildlife. Phil. Trans. R. Soc. B 2009, 364. 2027 - 2045.

Wright, S. L.; Thompson, R. C.; Galloway, T. S. The physical impacts of microplastics on marine organisms: a review. Environmental Pollution 2013, xxx. 1 - 10. 